УДК $629.765 \quad$ https://doi.org/10.35546/kntu2078-4481.2021.4.7

С.I. ВЛАДОВ

Кременчуцький льотний коледж Харківського національного університету внутрішніх справ, м. Кременчук ORCID 0000-0001-8009-5254

І.О. ДЄРЯБІНА

Кременчуцький льотний коледж Харківського національного університету внутрішніх справ, м. Кременчук ORCID 0000-0001-5164-2976

Н.В. ПОДГОРНИХ

Кременчуцький льотний коледж Харківського національного університету внутрішніх справ, м. Кременчук ORCID 0000-0002-1503-6896

C.А. ГРИБАНОВА

Кременчуцький льотний коледж Харківського національного університету внутрішніх справ, м. Кременчук ORCID 0000-0001-5831-2363

А.А. ЯНІЦЬКИЙ

Кременчуцький льотний коледж Харківського національного університету внутрішніх справ, м. Кременчук ORCID 0000-0001-5318-1915

\title{
ПРОБЛЕМИ І ПЕРСПЕКТИВИ ЗАСТОСУВАННЯ НЕЙРОННИХ МЕРЕЖ У ЗАДАЧАХ МОНІТОРИНГУ ТЕХНІЧНОГО СТАНУ АВІАЦЙНИХ ДВИГУНІВ ВЕРТОЛЬОТІВ У ПОЛЬОТНИХ РЕЖИМАХ
}

Для покращення показників якості систем автоматичного управління актуальною є задача розробки нових алгоритмів ідентифікації та діагностики технічних об'єктів. Одним із шляхів розв'язання задачі $\epsilon$ застосування штучних нейронних мереж. 3 метою дослідження проблем застосування штучних нейронних мереж для ідентифікаиії та діагностики технічних об'єктів, зокрема, авіачійних двигунів вертольотів, проведено аналіз наукових прачь з ичієї тематики за останні роки. Розглянуто існуючі підходи до побудови систем діагностики несправностей та систем автоматичного управління на основі штучних нейронних мереж. Результати наведеного аналізу можуть бути використані при розробиі нових методів та алгоритмів ідентифікації та діагностики технічних об'єктів на основі нейромережевих аналізаторів. У цій роботі як приклад наведена узагальнена нейромережева модель авіаційних двигунів вертольотів, що застосовується для моніторингу їх технічного стану в режимі польотів вертольотів. 3 даною моделлю у роботі сформульовано задача ідентифікації технічного стану авіаційних двигунів вертольотів. У цій роботі наведено приклад застосування нейромережевих технологій у задачах управління авіаційними двигунами вертольотів у польотних режимах. Розроблено структуру моделі управління авіаційними двигунами вертольотів у польотних режимах із застосуванням нейронної мережі архітектури персептрон. Отримані результати свідчать про переваги застосування нейронних мереж у задачах управління авіаційними двигунами вертольотів у польотних режимах перед іншими методами, наприклад, методом управління із застосуванням ПІД-регуляторів. 3 боку сучасних програмно-технічних засобів відсутні будь-які обмеження на складність використовуваних алгоритмів, проте для реалізації тих значних потенційних можливостей, які мають системи управління на основі штучних нейронних мереж, потрібна розробка концептуально нових підходів до побудови таких систем.

Ключові слова: штучна нейронна мережа, система автоматичного управління, ідентифікація, діагностика, нейрорегулятор.

С.И. ВЛАДОВ

Кременчугский летный колледж Харьковского национального университета внутренних дел, г. Кременчуг ORCID 0000-0001-8009-5254

И.А. ДЕРЯБИНА

Кременчугский летный колледж Харьковского национального университета внутренних дел, г. Кременчуг ORCID 0000-0001-5164-2976

Н.В. ПОДГОРНИХ

Кременчугский летный колледж Харьковского национального университета внутренних дел, г. Кременчуг ORCID 0000-0002-1503-6896

С.А. ГРИБАНОВА

Кременчугский летный колледж Харьковского национального университета внутренних дел, г. Кременчуг ORCID 0000-0001-5831-2363

А.А. ЯНИЦКИЙ

Кременчугский летный колледж Харьковского национального университета внутренних дел, г. Кременчуг ORCID 0000-0001-5318-1915 


\title{
ПРОБЛЕМЫ И ПЕРСПЕКТИВЫ ПРИМЕНЕНИЯ НЕЙРОННЫХ СЕТЕЙ В ЗАДАЧАХ МОНИТОРИНГА ТЕХНИЧЕСКОГО СОСТОЯНИЯ АВИАЦИОННЫХ ДВИГАТЕЛЕЙ ВЕРТОЛЕТОВ В ПОЛЕТНЫХ РЕЖИМАХ
}

\begin{abstract}
Для улучшения показателей качества систем автоматического управления актуальной является задача разработки новых алгоритмов идентификаџии и диагностики технических объектов. Одним из путей решения задачи является применение искусственных нейронных сетей. $B$ целях исследования проблем использования искусственных нейронных сетей для идентификации и диагностики технических объектов, в частности, авиационных двигателей вертолетов, проведен анализ научных работ по данной тематике за последние годы. Рассмотрены существующие подходы к построению систем диагностики неисправностей, а также систем автоматического управления на основе искусственных нейронных сетей. Результаты приведенного анализа могут быть использовань при разработке новых методов и алгоритмов идентификачии и диагностики технических объектов на основе нейросетевых анализаторов. В данной работе в качестве примера приведена обобщенная нейросетевая модель авиационных двигателей вертолетов, которая применяется для мониторинга их технического состояния в режиме полетов вертолетов. На основании данной модели в работе сформулирована задача идентификации технического состояния авиационных двигателей вертолетов. В данной работе приведен пример применения нейросетевых технологий в задачах управления авиационными двигателями вертолетов в полетных режимах. Разработана структура модели управления авиационными двигателями вертолетов в полетных режимах с применением нейронной сети архитектуры персептрон. Полученные результаты свидетельствуют о преимуществах применения нейронных сетей в задачах управления авиационными двигателями вертолетов в полетных режимах перед другими методами, например, методом управления с применением ПИД-регуляторов. Со сторонь современных программно-технических средств отсутствуют какие-либо ограничения на сложность используемых алгоритмов, однако для реализачии тех значительных потенциальных возможностей, которые имеют системы управления на основе искусственных нейронных сетей, требуется разработка концептуально новых подходов к построению таких систем.
\end{abstract}

Ключевые слова: искусственная нейронная сеть, система автоматического управления, идентификация, диагностика, нейрорегулятор.

S.I. VLADOV

Kremenchuk Flight College of Kharkiv National University of Internal Affairs, Kremenchuk ORCID 0000-0001-8009-5254

I.O. DIERIABINA

Kremenchuk Flight College of Kharkiv National University of Internal Affairs, Kremenchuk ORCID 0000-0001-5164-2976

N.V. PODHORNYKH

Kremenchuk Flight College of Kharkiv National University of Internal Affairs, Kremenchuk ORCID 0000-0002-1503-6896

S.A. HRYBANOVA

Kremenchuk Flight College of Kharkiv National University of Internal Affairs, Kremenchuk ORCID 0000-0001-5831-2363

A.A. YANITSKYI

Kremenchuk Flight College of Kharkiv National University of Internal Affairs, Kremenchuk ORCID 0000-0001-5318-1915

\section{PROBLEMS AND PROSPECTS OF THE USE OF NEURAL NETWORKS IN MONITORING TASKS OF HELICOPTERS AIRCRAFT ENGINES TECHNICAL STATE IN FLIGHT MODES}

To improve the quality indicators of automatic control systems, it is urgent to develop new algorithms for the identification and diagnostics of technical objects. One of the ways to solve the problem is the use of artificial neural networks. In order to study the problems of using artificial neural networks for the identification and diagnostics of technical objects, in particular, helicopters aircraft engines, an analysis of scientific works on this topic in recent years has been carried out. The existing approaches to the construction of fault diagnostics systems, as well as automatic control systems based on artificial neural networks, are considered. The results of the above analysis can be used in the development of new methods and algorithms for identification and diagnostics of technical objects based on neural network analyzers. In this paper, as an example, a generalized neural network model of helicopter aircraft engines is presented, which is used to monitoring their technical state in the helicopter flight mode. Based on this model, the paper formulates the problem of identifying the technical condition of helicopter aircraft engines. This paper provides an example of the use of neural network technologies in the control problems of helicopter aircraft engines in flight modes. The structure of the model for 
controlling helicopters aircraft engines in flight modes using a neural network of the perceptron architecture has been developed. The results obtained indicate the advantages of using neural networks in the problems of controlling helicopters aircraft engines in flight modes over other methods, for example, a control method using PID controllers. On the part of modern software and hardware, there are no restrictions on the complexity of the algorithms used, however, to realize the significant potential capabilities that control systems based on artificial neural networks have, it is necessary to develop conceptually new approaches to the construction of such systems.

Keywords: artificial neural network, automatic control system, identification, diagnostics, neuroregulatory.

\section{Постановка проблеми}

Нейронні мережі - розділ штучного інтелекту, в якому для обробки сигналів використовуються явища, аналогічні, що перебігають у нейронах живих істот [1]. Дослідженню штучних нейронних мереж (ШНМ), присвячені роботи вітчизняних авторів (В.А. Терехова, В.М. Лазарєва, А.П. Свиридова, А.Н. Горбань тощо), а також зарубіжних (С. Осовського, Ф. Уоссермена, А.К. Джейна тощо).

Основними функціями ШНМ є: сигналів;

- функція апроксимації, актуальна при розв'язанні задач моделювання, ідентифікації та обробки

- функція класифікації та розпізнавання образів, актуальна, наприклад, під час розв'язання задач діагностики стану об'єкта;

- функція прогнозування, актуальна в оцінюванні майбутнього поведінки системи 3 наявної послідовності її попередніх станів; процесами;

- функція ідентифікації та оцінювання, актуальна при розв'язанні задач управління динамічними

- функція асоціативного управління.

Аналіз зарубіжних досліджень, присвячених ШМН та нейрокомп'ютерам, дозволяє виділити такі перспективні напрямки сучасного розвитку нейромережевих та нейрокомп’ютерних технологій [2]:

- нейропакети;

- нейромережеві експертні системи;

- СУБД із використанням нейромережевих алгоритмів;

- обробка сигналів та зображень;

- управління динамічними системами;

- оптичні нейрокомп'ютери;

- системи віртуальної реальності.

Нині дослідженнями у цій галузі займається понад 300 зарубіжних фірм, причому їх постійно збільшується. Серед них Intel, DEC, IBM, Motorolla тощо. Спостерігається тенденція переходу від програмної до програмно-апаратної реалізації нейромережевих алгоритмів зі значним збільшенням числа розробок HBIC-нейрочіпів. Істотно збільшилася кількість військових розробок, орієнтованих на створення надшвидких, «розумних» суперЕОМ.

Аналіз останніх досліджень і публікацій

Широке застосування ШНМ знайшли для розв'язання задач медичної діагностики, а також при дослідженні та прогнозуванні різних економічних процесів та явищ, тобто там, де відсутні способи формального опису досліджуваних об'єктів та явищ.

У свою чергу, при розв'язанні технічних задач, таких, як ідентифікація об’єктів управління, синтез регуляторів, діагностика несправностей, застосування ШНМ досі досить обмежене. Частково це пояснюється наявністю розвиненого математичного апарату, що описує процеси та явища, що перебігають в об'єктах, а також наявністю великої кількості методів розв'язання зазначених задач. Незважаючи на це, в останні роки спостерігається позитивна динаміка щодо застосування ШНМ для розв'язання задач ідентифікації та діагностики несправностей технічних об'єктів. Наприклад, у роботах І.П. Добродєєва, А.С. Макарова, Д.С. Легконогих як об'єкт дослідження розглядаються авіаційний газотурбінний двигун (ГТД) та його система автоматичного управління (САУ), наводиться опис підходу до технічної діагностики авіаційних силових установок із застосуванням математичного апарату ШНМ [3], розглядаються проблеми підвищення ефективності нейромережевих методів розв'язання основних типів діагностичних задач ГТД шляхом оптимізації нейромережевих моделей на основі функціональної адаптації [4], а також підвищення оперативності та достовірності виявлення відмов САУ ГТД в умовах зміни режимів роботи двигуна та методики їхньої програмно-апаратної реалізації [5]. Розробці методів діагностики авіаційних ГТД за умов часткової втрати інформації присвячено дослідження [6]. Створенню методу оптимальної фрагментації нейронної мережі, що дозволяє створити апаратно-програмний комплекс на основі великих нейронних мереж, присвячено роботу С.Ю. Степанова [7]. Крім того, низка досліджень присвячена розв'язанню задач діагностики двигунів постійного струму із застосуванням 
нейромережевих моделей [8, 9], а також проблем оперативної діагностики стану мехатронного комплексу фонду електровідцентрових насосів нафтовидобувних свердловин 3 метою скорочення кількості їх відмов [10].

\section{Формулювання мети досліджень}

Метою даної роботи є обгрунтування застосування ШНМ для розв’язання прикладних задач моніторингу технічного стану авіаційних двигунів вертольотів у польотних режимах.

\section{Принцип побудови нейромережевої моделі складних технічних об’сктів}

На основі аналізу наведених джерел можна зробити висновок про те, що рівень розв'язання великої кількості задач аналізу та синтезу САУ нижчий за рівень потреб та можливостей розвитку наукових та технічних досягнень. Зокрема, актуальною $\epsilon$ проблема визначення та локалізації несправностей САУ, що проектуються на основі мікроконтролерів та мікропроцесорів. На рис. 1 представлена схема можливих шляхів пошуку несправностей залежно від стадії життєвого циклу виробу, а також досліджуваних каналів систем управління.

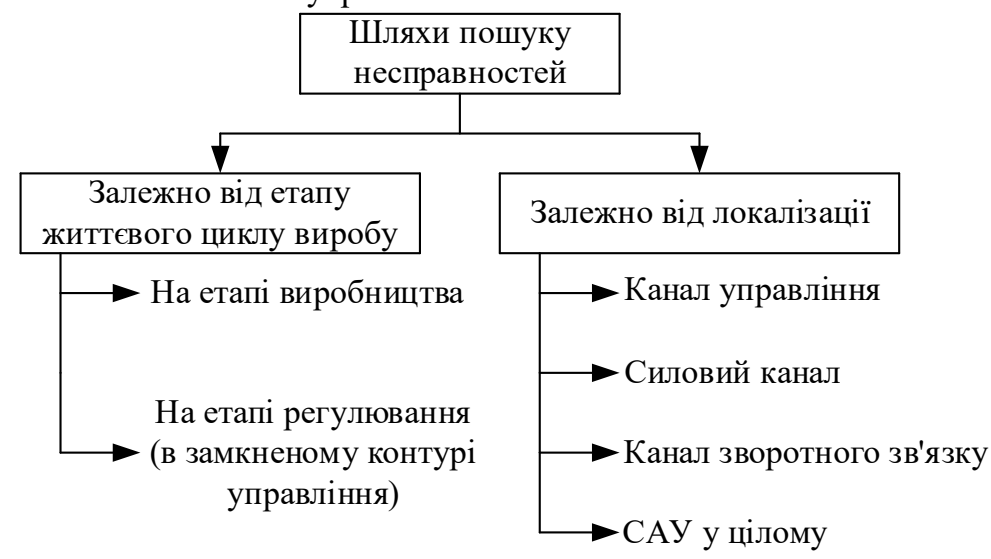

Рис. 1. Схема шляхів пошуку несправностей у САУ

Розробка та реалізація нових нетривіальних алгоритмів моніторингу та оперативної діагностики технічних об'єктів та САУ в цілому на основі ШНМ дозволить підвищити надійність пристроїв та водночас спростити їх конструкцію за рахунок виключення так званого «гарячого резервування», а також зменшити експлуатаційні витрати, витрати на технічне обслуговування та ремонт обладнання.

Однак при розробці алгоритмів діагностики та проектуванні САУ на основі ШНМ досі не вирішено низку проблем, головними з яких є такі [11]:

- відсутність формальних методів вибору типу ШНМ, адекватного розв'язуваному класу задач;

- недостатня обгрунтованість вибору методів оптимізації у процедурі навчання ШНМ, що призводить до великих помилок прогнозу та часу навчання;

- висока комбінаторна складність проблем, пов'язаних з автоматичним формуванням топології ШНМ, що у багатьох випадках не дозволяє створювати інтелектуальні інформаційні технології на базі ШНМ з мінімальною складністю.

У загальному вигляді алгоритм розв’язання задач апроксимації та класифікації із застосуванням ШНМ, відповідно до [1], представлений на рис. 2.

Оскільки в термінах ШНМ задача діагностики несправностей (як частинна задача комплексного моніторингу) відноситься до групи задач класифікації та розпізнавання образів, після постановки задачі та аналізу вхідних даних проводиться попередня обробка даних - так звана екстракція (визначення властивостей). Це пов'язано з тим, що опис самого образу повинен наводитися до виду, що забезпечує його незалежність від можливого переміщення, ротації та масштабування. Внаслідок такого перетворення формуються значення властивостей образу, що подаються для розпізнавання на вхід нейронної мережі, i, тому розроблено різні методи (метод статистичних моментів, метод перетворення Фур'є, хвильове перетворення, перетворення RSA, перетворення Карунена-Лоева тощо), вибір яких визначається специфікою розв'язуваної задачі. Далі слідує етап попереднього підбору архітектури мережі, який включає:

- вибір кількості шарів мережі;

- вибір кількості нейронів у кожному шарі;

- визначення необхідних зв'язків між шарами.

Рішення щодо вибору остаточної схеми мережі може бути прийняте лише після повноцінного навчання (зі зменшенням похибки до рівня, що визнається задовільним) різних варіантів ії структури. Етапу навчання передує підбір навчальних вибірок і додавання шуму в навчальні вибірки, оскільки для добре натренованої мережі стає актуальною задача вироблення у вихідних сигналів чутливості до 


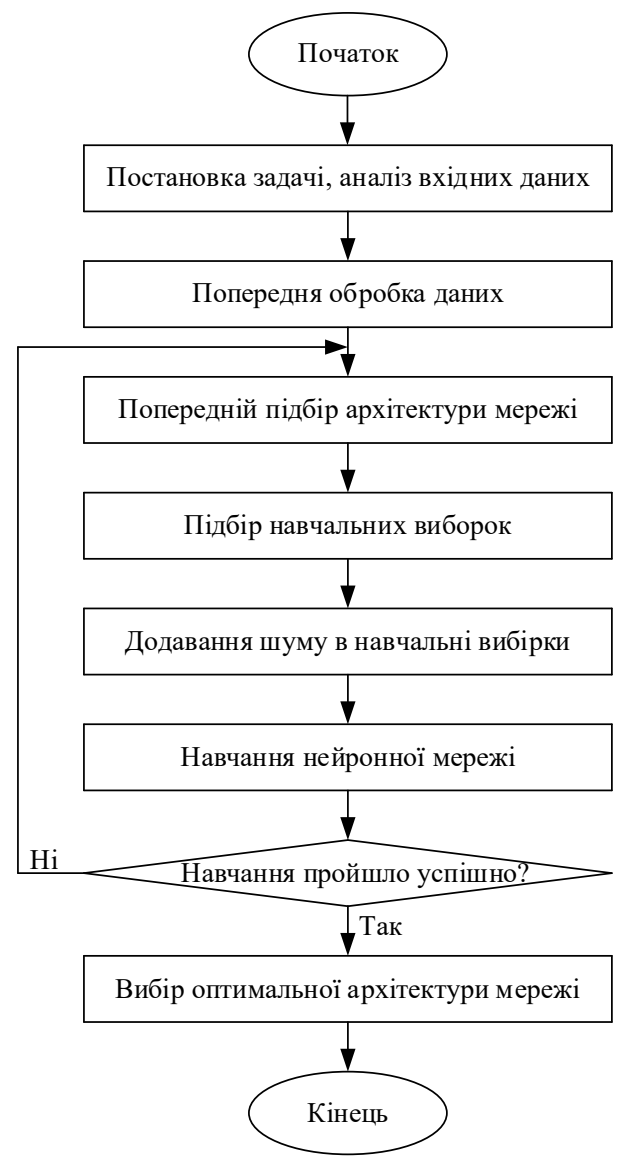

Рис. 2. Блок-схема алгоритму розв'язання задач апроксимації та класифікації із застосуванням ШНМ варіацій вхідних величин за умови, що вони знаходяться в певних допустимих межах, а мережа реалізує монотонне відображення.

Навчання мережі у разі розв'язання задачі діагностики несправностей (завдань класифікації та розпізнавання образів) проводиться найчастіше методом зворотного поширення помилки 3 використанням одного 3 навчальних алгоритмів на множині навчальних даних, що послідовно представляють всі класи образів, що підлягають розпізнаванню. У режимі відтворення класифікований образ, що пройшов через всі фази екстракції, подається на вхід мережі, збуджує вихідний нейрон, який відповідає необхідному класу.

Головним критерієм підбору оптимальної архітектури мережі є здатність до узагальнення. Мережа, натренована на деякій підмножині навчальних вибірок, генерує очікувані результати при подачі на ii вхід даних, що належать до тієї ж множини, але не брали участь безпосередньо у процесі навчання. Підбір оптимальної структури мережі зводиться до зменшення кількості прихованих нейронів і міжнейронних зв'язків, тобто, до редукції мережі за допомогою різних методів (3 урахуванням чутливості, 3 використанням штрафної функції тощо) або до нарощування мережі (алгоритми МезардаНадала, Мерчанда, метод Лі-Тафтса, алгоритм каскадної кореляції С. Фальмана).

Іншим перспективним напрямом застосування ШНМ, як було зазначено вище, є ідентифікація технічних об’єктів та управління динамічними процесами. Нині проблему практичного використання ШНМ у САУ вирішено лише частково. Недостатньо повно висвітлено питання застосування нейрорегуляторів у САУ, а також відсутні формальні методики побудови нейромережевих моделей об'єктів управління (ОУ) різної складності. $€$ приклади застосування рекурентних та нерекурентних ШНМ для розв'язання лише окремих частинних задач даного класу.

Разом 3 тим можна констатувати науковий інтерес, що збільшується, до даної галузі застосування ШНМ, особливо в останні роки. У цьому слід зазначити роботу В.Л. Єлісєєва [12], присвячену розробці та дослідженню нейромережевих алгоритмів управління стаціонарними та нестаціонарними об'єктами, а також роботи С. А. Агвамі [13] та А.А. Анісімова [14], що розглядають питання синтезу адаптивного нейрорегулятора для управління нелінійним багатозв'язним об'єктом та ідентифікації електромеханічних систем з використанням ШНМ. На особливу увагу заслуговує робота В.Б. Трофімова [15], в якій зроблено спробу вирішити в комплексі проблеми побудови та навчання нейромережевих моделей об'єктів у замкнутому контурі управління та сформувати науково-методичні засади розробки нейроекспертних розпізнавачів, які можуть бути застосовані при комплексному моніторингу технічного стану авіаційних ГТД вертольотів у польотних режимах.

Аналіз наведених джерел показує, що ідентифікація технічних об’єктів з використанням апарату ШНМ має наступні переваги:

- нейромережна модель ОУ при успішному навчанні є більш точною, ніж модель, в основі якої лежить передавальна функція, особливо при ідентифікації об'єктів високого порядку зі складним математичним описом;

- застосування нейромережевих моделей дає можливість моделювання динаміки ОУ у різних режимах, у тому числі, екстремальних, які неможливо відтворити на наявному лабораторному обладнанні;

- нейрорегулятори дозволяють синтезувати високоякісні САУ нестаціонарними об’єктами та об'єктами з розподіленими параметрами.

На рис. 3 наведена широко цитована у різних джерелах схема САУ з нейромережевою моделлю ОУ та нейрорегулятором, де НР - нейрорегулятор; ОУ - об'єкт управління; НМ - нейромережева модель 
ОУ; $q(t)$ - сигнал із задатчика; $r(t)$ - сигнал на вході НР; $u(t)$ - керуючий вплив, що формується НР; $f(t)-$ збуджуюча дія; $y(t)$ - сигнал на виході ОУ; $y^{\prime}(t)$ - сигнал на виході НM; $e(t)$ - сигнал помилки.

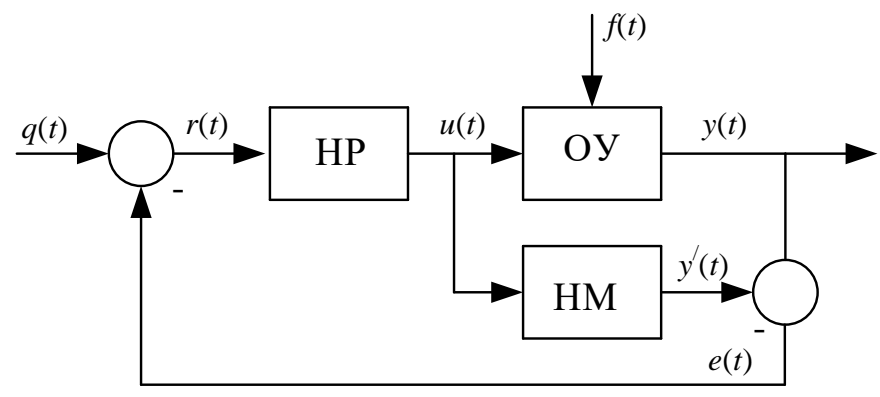

Рис. 3. Структурна схема САУ 3 нейромережевою моделлю ОУ та нейрорегулятором

Проте, недоліком даної схеми є те, що тут потрібно як мінімум уточнення алгоритму синтезу нейрорегулятора на основі інвертування нейромережевої моделі OУ, а також недостатньо явно простежується взаємозв'язок між підбором вагових коефіцієнтів НМ та НР. Крім того, потрібне додаткове опрацювання питання про можливість об'єднання НР та НМ в одну ШНМ.

Окрему проблему $\epsilon$ навчання нейромережевої моделі. Необхідно визначити найбільш інформативні методи ідентифікації, як серед традиційно застосовуваних 3 використанням експериментально знятих кривих розгону ОУ $y(t)$ при різних комбінаціях керуючих $u(t)$ і збуджуючих $f(t)$ впливів, кривих вибігу тощо, так і принципово нові, що враховують специфіку процесів навчання ШНМ.

Питання застосування в САУ астатичних нейрорегуляторів у наукових працях практично не висвітлено. Що стосується синтезу нейрорегуляторов дуже актуальною $є$ задача отримання нульової помилки регулювання під час використання в САУ нейромережевих аналогів ПІД-регулятора, астатических регуляторів стану та інших аналогічних систем.

Узагальнена нейромережева модель авіаційних ГТД вертольотів

Авіаційний ГТД вертольоту є складною технічною системою. Розвиток підходів моніторингу технічного стану ГТД йде у кількох напрямах: розробка нових фізичних принципів моніторингу, розробка діагностичних засобів та систем, удосконалення алгоритмічних процедур [16]. Актуальність питань моніторингу досить висока, враховуючи, що є тенденції до розробки ГТД з більшими ресурсами та 3 більшим експлуатаційним навантаженням. Ціна несправності, руйнування чи катастрофи надзвичайно висока, особливо, коли йдеться про людські життя. Розробка систем моніторингу дозволяє підвищити безпеку експлуатації ГТД.

Застосування нейронних при розробці моделей авіаційних ГТД вертольотів має низку незаперечних переваг, оскільки:

- класичні методи апроксимації функцій декількох змінних не дозволяють реалізувати прості механізми вибору структури математичних моделей, у той час як розробка нейромережевих моделей базується на використанні стандартних процедур вибору структури нейронної мережі і методів їх навчання;

- реалізація класичних методів інтерполяції на основі сплайн-функцій вимагає значних обчислювальних ресурсів, при цьому забезпечення обчислень у реальному масштабі часу, як правило, проблематично. Багатошарова організація нейронних мереж дозволяє виконувати паралельні обчислення (при апаратній реалізації нейронної мережі), що забезпечує розв'язок задачі апроксимації в реальному масштабі часу;

- за допомогою нейронної мережі досить просто будуються інверсні моделі авіаційних ГТД вертольотів, які використовуються в компенсуючих регуляторах.

На рис. 4 приведена узагальнена структурна схема процесу настройки параметрів (процедури навчання) нейромережевої моделі авіаційного ГТД вертольоту (на прикладі двигуна ТВ3-117), де $\mathbf{U}=\left(u_{1}\right.$, $\left.u_{2} \ldots, u_{m}\right)^{T}$ - вектор вхідних (керуючих) впливів; $\mathbf{Y}=\left(y_{1}, y_{2} \ldots, y_{m}\right)^{T}-$ вектор вихідних параметрів двигуна; $\mathbf{Y}^{\mathbf{H M}}=\left(y_{1}^{H M}, y_{2}^{H M}, \ldots, y_{n}^{H M}\right)^{T}$

нейронної мережі. 


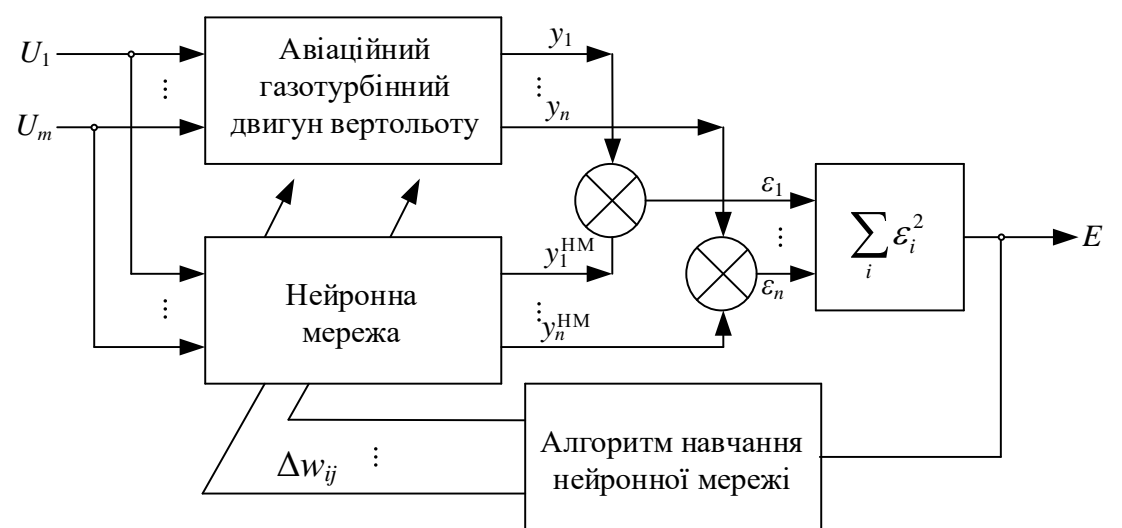

Рис. 4. Схема навчання нейромережевої моделі авіаційного ГТД вертольоту (на прикладі двигуна TB3-117)

Перетворення вектору управляючих впливів на вектор вихідних параметрів описується оператором F (який в загальному випадку може описувати статичну або динамічну модель):

$$
\mathrm{Y}=\mathrm{F}(\mathrm{U}) \text {. }
$$

Задача ідентифікації авіаційного ГТД вертольоту за допомогою ШНМ може бути сформульована наступним чином. За підсумками пропонованих нейронної мережі в процесі навчання множини векторів $\left(\mathrm{U}_{i} ; \mathrm{Y}_{i}\right)$, що утворюють «навчальну вибірку» $\mathrm{i}$ отриманих експериментальним шляхом для індивідуального екземпляра двигуна, необхідно відшукати оператор $\mathrm{F}^{\mathrm{HM}}$ в класі нейромережевих архітектур, який найкращим чином представляв би (апроксимував) оператор F.

Апроксимація оператора $\mathrm{F}$ оператором $\mathrm{F}^{\mathrm{HM}}$ може вважатися найкращою, якщо деякий

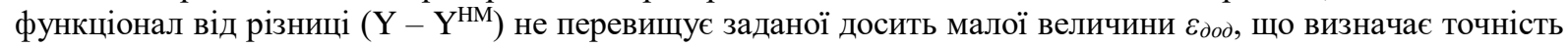
апроксимації оператора $F$ :

$$
E=\left\|\mathbf{Y}-\mathbf{Y}^{\mathrm{HM}}\right\|=\sum_{i}^{n} \varepsilon_{i}^{2} \leq \varepsilon_{\text {до }} ;
$$

Виконання умови (2) забезпечується шляхом навчання нейронної мережі, тобто настройки ії параметрів на навчальній вибірці $\{(\mathrm{U}, \mathrm{Y})\}$ і перевірясться на спеціальним чином організованій «тестовій вибірці».

\section{Приклад застосування нейромережевих технологій в задачах управління авіаційними газотурбінними двигунами вертольотів у польотних режимах}

Відомо, що нейроуправління - це окремий випадок інтелектуального управління, що використовує штучні нейронні мережі на вирішення задач управління складними динамічними об'єктами. Нейроуправління знаходиться на стику таких дисциплін, як штучний інтелект, нейрофізіологія, теорія автоматичного управління, робототехніка тощо. Нейронні мережі мають низку унікальних властивостей, що робить ї потужним інструментом для створення систем управління: здатністю до навчання на прикладах та узагальнення даних, здатністю адаптуватися до зміни властивостей об'єкта управління та зовнішнього середовища, придатністю для синтезу нелінійних регуляторів, високою стійкістю до пошкоджень своїх елементів у силу спочатку закладеного в нейромережеву архітектуру паралелізму. У роботі [17] було проведено дослідження існуючих методів нейроуправління, за результатами якого було обрано метод гібридного нейроуправління щодо випробувань складних динамічних об’єктів. Розглянемо як об’єкт управління авіаційним ГТД ТВ3-117, що входить до складу силової установки вертольоту Мі-8МТВ. Спрощена модель ГТД ТВ3-117 описується такими рівняннями:

- рівняння кута дозатора газу:

$$
\dot{A}_{D I}=a_{11} \cdot A_{D I}+a_{12} \cdot G_{T}+a_{13} \cdot n_{T K} ;
$$

- рівняння витрати палива:

$$
\dot{G}_{T}=a_{21} \cdot A_{D I}+a_{22} \cdot G_{T}+a_{23} \cdot n_{T K} ;
$$

- рівняння частоти обертання ротора турбокомпресора:

$$
\dot{n}_{T K}=a_{31} \cdot A_{D I}+a_{32} \cdot G_{T}+a_{33} \cdot n_{T K} ;
$$

- рівняння частоти обертання ротора вільної турбіни:

$$
\dot{n}_{C T}=a_{41} \cdot G_{T}+a_{42} \cdot n_{T K}+a_{43} \cdot n_{C T}+a_{44} \cdot A_{D I}+a_{45} \cdot M_{K R} \cdot
$$


Кут дозатора газу $A_{D I}$ регулює кількість палива $G_{T}$, що поступає, в результаті обертається турбіна компресора $n_{T K}$, обертання переходить на вільну турбіну $n_{C T}$, на яку подається навантаження $M_{K R}$

У процесі досліджень було розглянуто різні моделі нейроуправління. Для управління авіаційним ГТД ТВ3-117 було вирішено реалізувати варіант гібридного нейро-ПІД-управління без входу, на який надходить помилка із затримкою за часом. Дане рішення дещо ускладнює процес навчання та робить нейронну мережу більш прив'язаною до конкретного перехідного процесу, тобто. до конкретної спрощеної моделі. Побудова мережі, що відповідає різним спрощеним моделям, можлива, але залишається питання про швидкодію такої мережі в реальних умовах.

У результаті проведених експериментів було обрано такі параметри нейронної мережі: 1) тип багатошаровий персептрон; 2) кількість прихованих шарів - два; 3) кількість нейронів у першому шарі п’ятнадцять; 4) кількість нейронів у другому шарі - двадцять; 5) кількість нейронів у вихідному шарі три; метод навчання нейронної мережі - навчання з учителем за допомогою алгоритму зворотного поширення похибки [18].

Загальна структура моделі управління представлена на рис. 5. При моделюванні керуючою величиною є кут дозатора газу $A_{D I}$, а керованою - частота обертання ротора вільної турбіни $n_{C T}$. У роботі проведено порівняння вихідного графіка перехідного процесу з застосуванням ПІД-управління із графіком перехідного процесу із застосуванням гібридного нейро-ПІД-управління, результуючий графік представлено на рис. 6 .
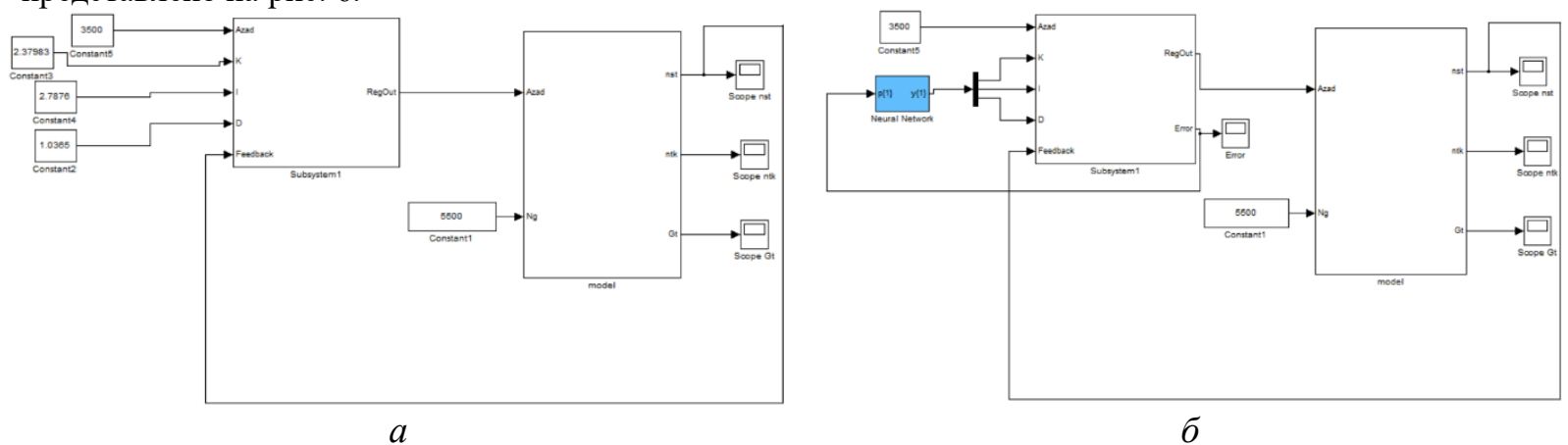

Рис. 5. Загальна структура моделі: $a$ - без нейронної мережі; $\sigma$ - із застосуванням нейронної мережі

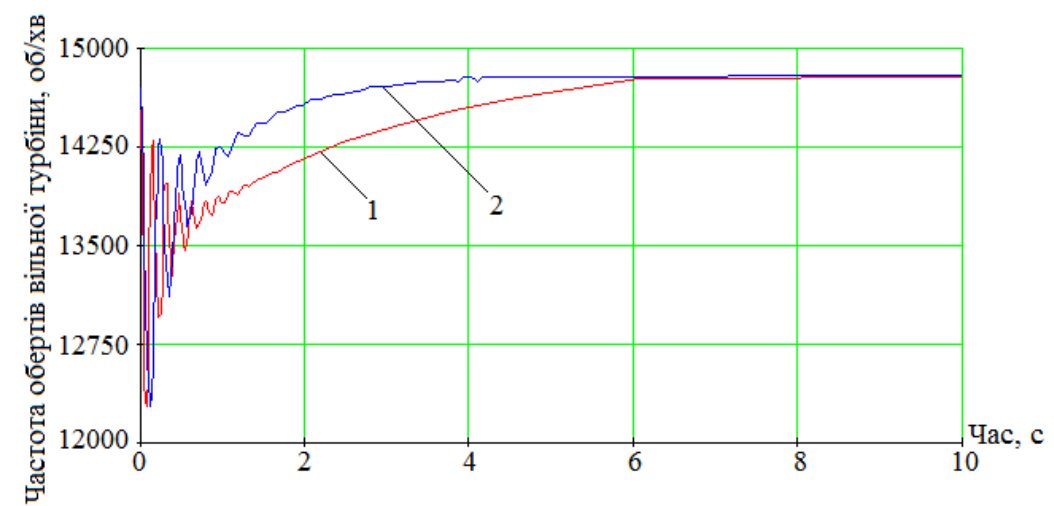

Рис. 6. Графік перехідного процесу: 1 - вихідний графік із застосуванням ПІД-управління; 2 вихідний графік із застосуванням гібридного нейро-ПІД-управління

3 рис. 2 видно, що при застосуванні гібридного нейро-ПІД-управління поліпшені наступні показники якості регулювання: помилка в режимі, що встановився, перерегулювання і час перехідного процесу, кількість коливань за час перехідного процесу. Порівняння систем $є$ виправданим, оскільки налаштування ПІД-регулятора у першому експерименті $\epsilon$ відправною точкою для налаштування нейронної мережі. Отриманий результат підтверджує можливість застосування гібридного нейро-ПІДуправління в рамках задачі, що розв'язується.

\section{Висновки}

На теперішній час найбільш перспективним є використання ШНМ для розв'язання задач діагностики та прогнозування, насамперед, у галузях, де відсутні способи формального опису досліджуваних об'єктів чи явищ. Для розв'язання задач ідентифікації та діагностики технічних об'єктів за допомогою ШНМ потрібна розробка формальних методів вибору вихідного опису об'єкта, типу ШНМ, обгрунтованого вибору алгоритму навчання ШНМ та методів оптимізації у процедурі навчання. У термінах ШНМ задача ідентифікації технічного об’єкта належить до класу задач апроксимації, а завдання діагностики несправностей - до групи завдань класифікації та розпізнавання образів. В останні 
роки спостерігається тенденція переходу від програмної до програмно-апаратної реалізації нейромережевих алгоритмів. 3 боку сучасних програмно-технічних засобів відсутні будь-які обмеження на складність використовуваних алгоритмів, проте для реалізації тих значних потенційних можливостей, що мають системи управління на основі ШНМ, потрібна розробка концептуально нових підходів до побудови таких систем.

\section{Список використаної літератури}

1. Осовский С. Нейронные сети для обработки информации / пер. с польского И. Д. Рудинского. Москва : Финансы и статистика, 2002. 344 с.

2. Лазарев В. М., Свиридов А. П. Нейросети и нейрокомпьютеры. Москва : Издательство МГТУ РЭА, 2011. $131 \mathrm{c}$.

3. Легконогих Д. С. Применение нейросетевых технологий в системах диагностики авиационных силовых установок. Известия Самарского научного центра Российской академии наук. 2012. Т. 14. № 4 (2). С. 639-643.

4. Добродеев И. П. Повышение эффективности нейросетевых моделей в системах диагностики технического состояния газотурбинных двигателей на основе функциональной адаптации : дис. ... канд. техн. наук. Рыбинск, 2010. 218 с.

5. Макаров А. С. Алгоритмы контроля и диагностики систем управления авиационными ГТД на основе нейросетевых моделей и нечеткой логики : дис. ... канд. техн. наук. Уфа, 2011. 207 с.

6. Метод диагностирования авиационных двигателей в условиях частичной потери информации / Е. Копытов, В. Лабендик, А. Осис, А. Тарасов. Авиадвигатели ХХI века : труды II Международной научно-технической конференции, 2005. С. 246-247.

7. Степанов С. Ю. Проектирование процедур организации управления объектами машиностроения на основе аппарата фрагментации больших нейронных сетей : дис. ... канд. техн. наук. Москва, 2011. $152 \mathrm{c}$.

8. Скалозуб В. В., Швец О. М. Нейросетевые модели диагностики электродвигателей постоянного тока. Інформаційно-керуючі системи на залізничному транспорті. 2009. № 4. С. 7-11.

9. Керенцев Е. В. Анализ методов диагностирования двигателей постоянного тока на автомобиле. Вектор науки Тольяттинского государственного университета. 2011. № 3(17). С. 50-53.

10. Коровин Я. С. Методы и средства оперативной диагностики состояния электроцентробежных насосов нефтедобывающих скважин на основе нейронных сетей : дис. ... канд. техн. наук. Таганрог, 2011. $162 \mathrm{c}$.

11. Воеводин Ю. Ю. Методы и алгоритмы структурно-параметрического синтеза нейросетевой модели для формирования интеллектуальных информационных технологий : дис. ... канд. техн. наук. Волгоград, 2009. $153 \mathrm{c}$.

12. Елисеев В. Л. Разработка и исследование нейросетевых алгоритмов управления стационарными и нестационарными объектами : дис. ... канд. техн. наук. Москва, 2012. 208 с.

13. Агвами С. А., Коломейцева М. Б. Синтез адаптивного нейрорегулятора для управления нелинейным многосвязным объектом. Вестник Московского энергетического института. 2011. № 6. C. 209-215.

14. Анисимов А. А., Горячев М. Н. Идентификация электромеханических систем с использованием искусственной нейронной сети. Вестник Ивановского государственного энергетического университета. 2008. Вып. 3. С. 55-58.

15. Трофимов В. Б. Методы и алгоритмы построения нейроэкспертных систем автоматического контроля и управления технологическими процессами (на примере черной металлургии) : дис. ... канд. техн. наук. Новокузнецк, 2008. 189 с.

16. Tudosie A.-N. Aircraft Gas-Turbine Engine's Control Based on the Fuel Injection Control. Aeronautics and Astronautics, Intech, Rijeka, Croatia, 2011. 2011. Pp. 305-331.

17. Бахирев И. В. Нейросетевые модели управления в задачах испытания САУ ГТУ. Инноваиионные технологии: теория, инструменты, практика (INNOTЕCH 2012). 2013. С. 66-71.

\section{References}

1. Osovskiy, S. Neyronnye seti dlya obrabotki informatsii [Artificial Neural Networks for Information Processing]. Moscow, Finansy i statistika, 2002, 344 p.

2. Lazarev, V. M., Sviridov, A. P. Neyroseti i neyrokomp'yutery [Neural Networks and Neural Computers]. Moscow, MGTU REA, 2011, 131 p.

3. Legkonogikh, D. S. (2012), "Primenenie nejrosetevyh tekhnologij v sistemah diagnostiki aviacionnyh silovyh ustanovok" [Application of neural network technologies in diagnostic systems of aircraft power plants], Izvestiya Samarskogo nauchnogo tsentra Rossiyskoy akademii nauk, vol. 14, issue 4(2), pp. 639-643.

4. Dobrodeev, I.P. Povyshenie effektivnosti neyros- etevykh modeley $v$ sistemakh diagnostiki tekhnicheskogo sostoyaniya gazoturbinnykh dvigateley na osnove funktsional'noy adaptatsii. Diss. kand. tekhn. 
nauk [Increasing the Efficiency of Neural Networks Models in Gas Turbine Engine Diagnostic Systems based on Functional Adaptation. Cand. tech. sci. diss.]. Rybinsk, 2010. 218 p.

5. Makarov, A.S. Algoritmy kontrolya I diagnostiki system upravleniya aviatsionnymi GTD na osnove neyrosetevykh modeley $i$ nechetkoy logiki. Diss. kand. tekhn. nauk [Control and Diagnostic Algorithms for Aviation Gas Turbine Engine Control Systems based on Neural Networks Models and Fuzzy Logic. Cand. tech. sci. diss.]. Ufa, 2011. 207 p.

6. Kopytov, E., Labendik, V., Osis, A., Tarasov, A. (2005), "Metod diagnostirovaniya aviatsionnykh dvigateley v usloviyakh chastichnoy poteri informatsii" [Aviation Engine Diagnostic Method in Condition of Partial Information Losses], Trudy II Mezhdunarodnoy nauchno-tekhnicheskoy konferentsii «Aviadvigateli XXI veka» [Works of the II-nd International Scientific and Technical Conference «AviaEngines of the XXI century»]. Moscow, 2005, pp. 246-247.

7. Stepanov, S. Yu. Proektirovanie protsedur organizatsii upravleniya ob»ektami mashinostroeniya na osnove apparata fragmentatsii bol'shikh neyronnykh setey. Diss. kand. tekhn. nauk [Designing the Control Organization Procedures of Maching-building Objects on the basis of Fragmentation Apparatus of Big Neural Networks. Cand. tech. sci. diss.]. Moscow, 2011. 152 p.

8. Skalozub, V. V., Shvets, O. M. (2009), "Nejrosetevye modeli diagnostiki elektrodvigatelej postoyannogo toka" [Neural network models for diagnostics of DC motors], IKSZT, issue 4, pp. 7-11.

9. Kerentsev, E. V. (2011), "Analiz metodov diagnostirovaniya dvigatelej postoyannogo toka na avtomobile" [Analysis of diagnostic methods for DC motors on a car], Vektor nauki TGU, issue 3(17), pp. 50-53.

10. Korovin, Ya. S. Metody i sredstva operativnoy diagnostiki sostoyaniya elektrotsentrobezhnykh nasosov neftedobyvayushchikh skvazhin na osnove neyronnykh setey. Diss. kand. tekhn. nauk [Operative Diagnostic Methods and Means for Electric Centrifugal Pumps of Oil Wells based on Artificial Neural Networks. Cand. tech. sci. diss.]. Taganrog, 2011. 162 p.

11. Voevodin, Yu. Yu. Metody i algoritmy strukturno-parametricheskogo sinteza neyrosetevoy modeli dlya formirovaniya intellektual'nykh informatsionnykh tekhnologiy. Diss. kand. tekhn. nauk [Methods and Algorithms of Structural and Parametric Synthesis of Neural Network Model for Developing the Intellectual Information Technologies. Cand. tech. sci. diss.]. Volgograd, 2009. 153 p.

12. Eliseev, V. L. Razrabotka i issledovanie neyrosetevykh algoritmov upravleniya statsionarnymi $i$ nestatsionarnymi ob»ektami. Diss. kand. tekhn. nauk [Development and Research of Neural Networks Control Algorithms for Stationary and Nonstationary Objects. Cand. tech. sci. diss.]. Moscow, 2012. 208 p.

13. Agvami, S. A., Kolomeytseva, M. B. (2011), "Sintez adaptivnogo nejroregulyatora dlya upravleniya nelinejnym mnogosvyaznym ob'ektom" [Synthesis of an adaptive neuroregulator for control of a nonlinear multiply connected object], Vestnik MEI, issue 6, pp. 209-215.

14. Anisimov, A. A., Goryachev, M. N. (2008), "Identifikaciya elektromekhanicheskih sistem s ispolzovaniem iskusstvennoj nejronnoj seti" [Identification of electromechanical systems using an artificial neural network], Vestnik IGEU, issue 3, pp. 55-58.

15. Trofimov, V. B. Metody i algoritmy postroeniya neyroekspertnykh sistem avtomaticheskogo kontrolya i upravleniya tekhnologicheskimi protsessami (na primere chernoy metallurgii). Diss. kand. tekhn. nauk [Methods and Algorithms of Neuro-expert automatic control systems designing for technological processes (the example of the steel industry). Cand. tech. sci. diss.]. Novokysnetsk, 2008. 189 p.

16. Tudosie A.-N. (2011), “Aircraft Gas-Turbine Engine's Control Based on the Fuel Injection Control”, Aeronautics and Astronautics, Intech, Rijeka, Croatia, 2011, pp. 305-331.

17. Bahirev, I. V. (2013), "Nejrosetevye modeli upravleniya v zadachah ispytaniya SAU GTD" [Neural network control models in the tasks of testing ACS GTE], Innovative technologies: theory, tools, practice (INNOTECH 2012), pp. 66-71. 